\title{
Decomposition of atrazine traces in water by combination of non-thermal electrical discharge and adsorption on nanofiber membrane
}

\author{
Patrick Vanraes ${ }^{a, *}$, Gert Willems ${ }^{a}$, Nele Daels ${ }^{b, c}$, Stijn W.H. Van Hulle ${ }^{c}$, \\ Karen De Clerck ${ }^{b}$, Pieter Surmont ${ }^{d}$, Frederic Lynen ${ }^{d}$, Jeroen Vandamme ${ }^{e}$, \\ Jim Van Durme ${ }^{e}$, Anton Nikiforou ${ }^{a, f}$, Christophe Leys ${ }^{a}$ \\ a Department of Applied Physics, Ghent University, Sint-Pietersnieuwstraat 41 B4, 9000 Ghent, Belgium \\ b Department of Textiles, Ghent University, Technologiepark 907, 9052 Zwijnaarde, Belgium

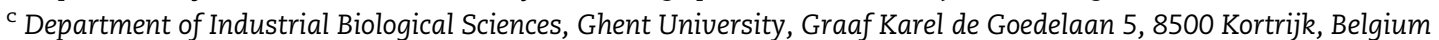 \\ d Separation Science Group, Department of Organic Chemistry, Universiteit Gent, Krijgslaan 281 S4-bis, 9000 Gent, \\ Belgium \\ ${ }^{\mathrm{e}}$ Research Group Molecular Odor Chemistry, Department of Microbial and Molecular Systems (M2S), KU Leuven, \\ Technology Campus, Gebroeders De Smetstraat 1, 9000 Ghent, Belgium \\ ${ }^{\mathrm{f}}$ Institute of Solution Chemistry RAS, Academicheskaya 1, 153012 Ivanovo, Russia
}

\section{A R T I C L E I N F O}

Article history:

Received 1 June 2014

Received in revised form

2 November 2014

Accepted 8 November 2014

Available online $\mathrm{xxx}$

Keywords:

Dielectric barrier discharge

Wastewater treatment

Advanced oxidation processes

Peroxone

Energy efficiency

Degradation by-products

\begin{abstract}
A B S T R A C T
In recent decades, several types of persistent substances are detected in the aquatic environment at very low concentrations. Unfortunately, conventional water treatment processes are not able to remove these micropollutants. As such, advanced treatment methods are required to meet both current and anticipated maximally allowed concentrations. Plasma discharge in contact with water is a promising new technology, since it produces a wide spectrum of oxidizing species. In this study, a new type of reactor is tested, in which decomposition by atmospheric pulsed direct barrier discharge (pDBD) plasma is combined with micropollutant adsorption on a nanofiber polyamide membrane. Atrazine is chosen as model micropollutant with an initial concentration of $30 \mu \mathrm{g} / \mathrm{L}$. While the $\mathrm{H}_{2} \mathrm{O}_{2}$ and $\mathrm{O}_{3}$ production in the reactor is not influenced by the presence of the membrane, there is a significant increase in atrazine decomposition when the membrane is added. With membrane, $85 \%$ atrazine removal can be obtained in comparison to only $61 \%$ removal without membrane, at the same experimental parameters. The by-products of atrazine decomposition identified by HPLC-MS are deethylatrazine and ammelide. Formation of these by-products is more pronounced when the membrane is added. These results indicate the synergetic effect of plasma discharge and pollutant adsorption, which is attractive for future applications of water treatment.
\end{abstract}

(c) 2014 Elsevier Ltd. All rights reserved.

\footnotetext{
* Corresponding author.

E-mail address: patrick.vanraes@ugent.be (P. Vanraes). http://dx.doi.org/10.1016/j.watres.2014.11.009

0043-1354/@ 2014 Elsevier Ltd. All rights reserved.
} 


\section{Introduction}

Throughout the EU, effluents of wastewater treatment plants deteriorate the chemical and biological status of surface waters (Schwarzenbach et al., 2006). New and largely unknown persistent substances, including pharmaceuticals, pesticides and compounds that disrupt the hormonal balance in humans, appear in the aquatic environment (Bolong et al., 2009; Ternes et al., 2004). In spite of their low concentrations, they have a high impact on water quality. The European Water Framework Directive is extending the scope of pollution control measures to protect surface water (EC, 2000). The recent report, 'European waters - assessment of status and pressures', published by the European Environment Agency (EEA, 2012), concludes that the actual ecological status with respect to persistent micropollutants is worse than desired. Due to the chemical properties of some pesticides and pharmaceuticals, their removal in wastewater treatment plants is often incomplete (Sunka, 2001; Bruggeman and Leys, 2009; Grymonpre et al., 2004). This causes micropollutants to find their way into natural water and eventually drinking water. Therefore, novel treatment technologies have to be developed if current and anticipated criteria for effluent and drinking water are to be met. Among the different advanced oxidation processes (AOP) that are under investigation, the use of low temperature plasma may prove to be a sustainable approach (UKWIR, 2009). Within the field of applied plasma science, electrical discharges in contact with water, in literature also referred to as "liquid plasmas", have received a lot of attention during the last decade (Sunka, 2001; Bruggeman and Leys, 2009), with water treatment as one of the main possible applications. Liquid plasma is a source of oxidizing species $(\mathrm{OH}$, $\mathrm{H}_{2} \mathrm{O}_{2}, \mathrm{O}_{3}$, atomic $\mathrm{O}$, singlet $\mathrm{O}_{2}$, and UV/VUV photons) that can initiate decomposition of organic pollutants dissolved in water (Grymonpre et al., 2004). Among various plasma reactor concepts that have been investigated (Nikiforov and Leys, 2006; Lukes et al., 2013; Sugiarto et al., 2003), pulsed power systems have been found to be the most efficient. By applying high voltage pulses, non-equilibrium plasmas with a relatively large active volume and a low gas temperature can be generated in the gas phase above liquid (Lukes et al., 2005).

Despite the progress that has been made in the engineering of liquid plasma systems, important research questions need to be answered to more deeply understand and optimize the oxidation mechanisms. First of all, up to now, only plasma initiated decomposition of a few very simple compounds have been studied in detail, e.g. phenol (Grabowski et al., 2006), sulfonol (Bobkova et al., 2012) and textile dyes (Benetoli et al., 2012). Moreover, when decomposition of common micropollutants in a plasma reactor is investigated, high concentrations in $\mathrm{mg} / \mathrm{L}$ range are used for simplicity in many cases. Since their concentration in wastewater and natural water typically ranges up to $\mu \mathrm{g} / \mathrm{L}$ only, more research is required that focusses on micropollutant removal in this lower range, as for example in the present study.

Secondly, degradation efficiency can be increased by enlarging the surface of the plasma-liquid interface by dispersion of micro-drops in the discharge (Locke and Thagard, 2009) or by forming a thin layer of liquid on one of the electrodes (Dojcinovic et al., 2011; Magureanu et al., 2008). The idea within this study is to further improve the latter concept with an additional step of adsorption of micropollutants on a nanofiber membrane placed on the electrode surface. The extremely high surface area of the nanofiber membrane, as described in Section 2.2, allows to reach higher micropollutant concentration at its surface, close to the active plasma region (Toth, 2002). There, reaction with active plasma species can take place and remove the micropollutants. This explains the expected synergy of plasma combined with pollutant adsorption.

In the present work, the pesticide atrazine is used as model micropollutant, since it is a good representative of persistent micropollution in water and stated in EU protocol as a dangerous pollutant. The applied concentration $(30 \mu \mathrm{g} / \mathrm{L})$ is one order of magnitude higher than the maximally allowed concentration in drinking water as defined by the United States Environmental Protection Agency (U.S. EPA, 2007), and the World Health Organization (WHO, 2008) and two orders of magnitude higher than the limit defined by the European Parliament and the Council (EC, 2006). In the first part of this work, the kinetics of $\mathrm{H}_{2} \mathrm{O}_{2}$ and $\mathrm{O}_{3}$ production under plasma action is investigated, as they are well known to be responsible for atrazine oxidation in AOPs. The second part of the paper deals with investigation of atrazine removal by the combination of non-thermal plasma and adsorption on nanofiber membrane and investigation of the by-products of atrazine oxidation.

\section{Materials and methods}

\subsection{DBD reactor for water treatment}

The atrazine solution was treated in pulsed dielectric barrier discharge ( $\mathrm{pDBD}$ ) generated above the solution. The scheme of the setup is presented on Fig. 1. The discharge was generated in between the high voltage electrode (HV) covered by a layer of dielectric material with thickness of about $360 \mu \mathrm{m}$ and a $0.3 \mathrm{~mm}$ thick water film formed on the surface of nanofiber membrane. The membrane was placed on the support made from porous Robu glass which was used to distribute water uniformly on the membrane surface. The distance between the HV electrode and water surface can be controlled with micro-screw. The radius of $\mathrm{HV}$ electrode is $11 \mathrm{~mm}$ and the radius of Robu porous glass is $20 \mathrm{~mm}$. In the present study we used HV pulse duration of $400 \mathrm{~ns}$ in order to generate the discharge. The pulsed system was based on solid state switch technology from Behlke. The HV switch was connected to positive output of DC high voltage power supply IO BRANDENBURG. The main parameters of the system are presented in Table 1.

The voltage was measured with a Tektronix $\mathrm{P} 6015 \mathrm{HV}$ probe and the current was measured with a Pearson model 2877 current probe. The short duration of HV pulses is favorable to generate a uniform discharge and to keep the gas temperature low. In all our experiments the water temperature never exceeded $35^{\circ} \mathrm{C}$ which means that the pDBD plasma has a low gas temperature and can be used for water treatment. The discharge was generated in dry air which is continuously 


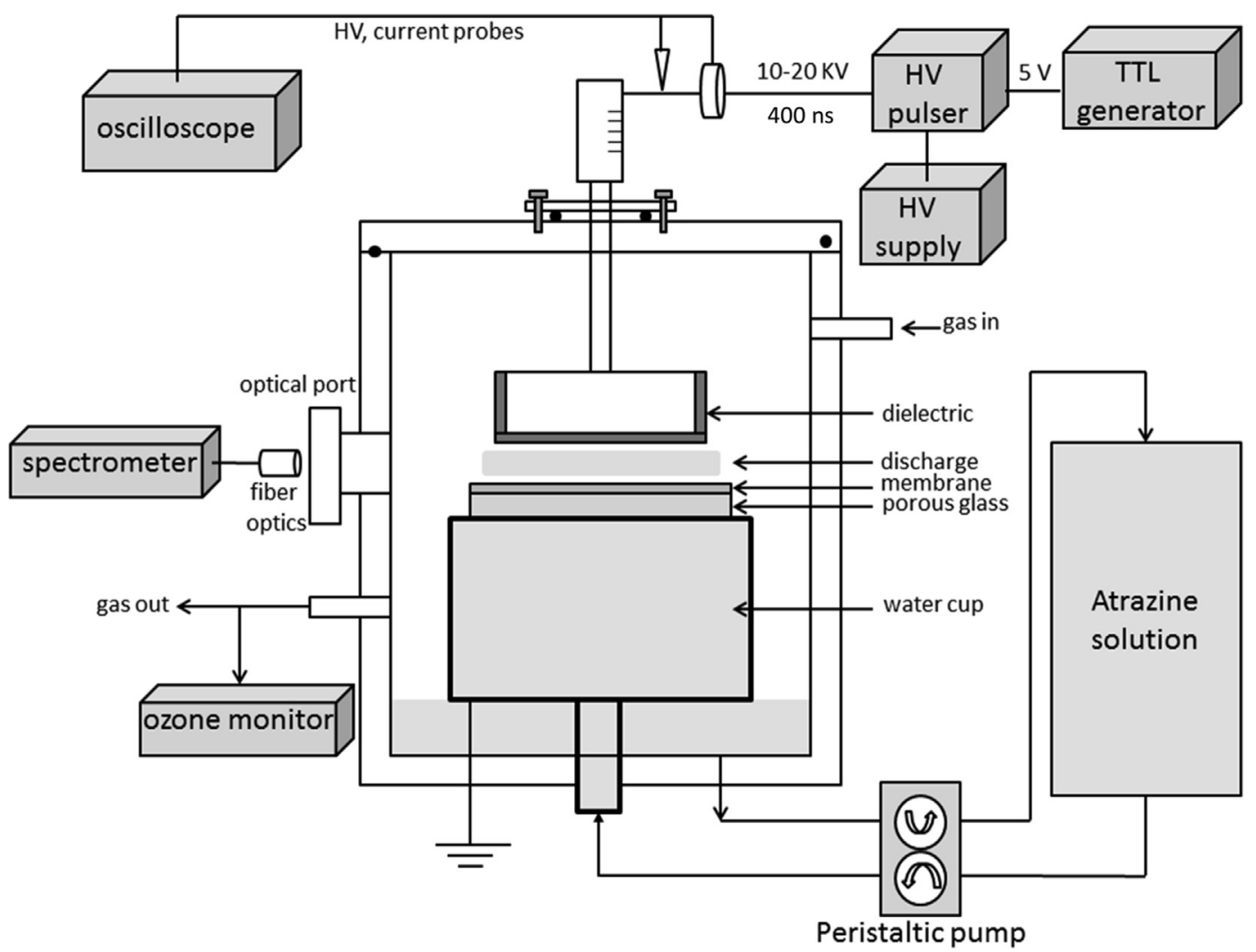

Fig. 1 - The scheme of the pDBD reactor and diagnostics used to control the performance of the process.

pumped through the system at a flow rate of 0.5 SLM (Standard Liter per Minute). The gas outlet was connected to the ozone monitor. The water solution was pumped in a closed circuit through the polyamide membrane, on which a thin water layer is formed. Atrazine, a persistent and hazardous pesticide, was chosen as a model micropollutant in our experiments, with an initial concentration of $30 \mu \mathrm{g} / \mathrm{L}$. Initial conductivity was set by addition of $\mathrm{NaH}_{2} \mathrm{PO}_{4} \cdot 2 \mathrm{H}_{2} \mathrm{O}$. The solution was pumped through the system with a 2-channel peristaltic pump at a flow rate of $18 \mathrm{~mL} / \mathrm{min}$ and $2 \mathrm{~mL}$ of solution is taken during the experiments for analysis by means of GC-MS, HPLC-MS and to measure $\mathrm{H}_{2} \mathrm{O}_{2}$ production. Additionally, emission spectra of the discharge are measured with OceanOptics spectrometer S1000 in the range of $250-900 \mathrm{~nm}$ in order to identify the main active species produced in the pDBD.

\section{Table 1 - The experimental parameters used in this} work.

\begin{tabular}{lc} 
Experimental parameter & Value/Description \\
\hline Discharge voltage & $23 \mathrm{kV}$ \\
HV Polarity & positive \\
Discharge power & $1.7 \mathrm{~W}$ \\
Inter-electrode distance & $2.75 \mathrm{~mm}$ \\
Pulsed frequency & $300 \mathrm{~Hz}$ \\
Robu glass porosity & 0.42 \\
Porous glass thickness & $3 \mathrm{~mm}$ \\
Treated volume & $100 \mathrm{~mL}$ \\
Initial atrazine concentration & $30 \mu \mathrm{g} / \mathrm{L}$ \\
Initial conductivity & $350 \mu \mathrm{S} / \mathrm{cm}$ \\
Initial pH & 5.06 \\
Treatment time & $45 \mathrm{~min}$ \\
\hline
\end{tabular}

\subsection{Nanofiber membrane}

The membrane is made on the setup with a scaled up multi nozzle system, developed at Ghent University, which is described in details by Decostere et al. (2009) and Daels et al. (2010). Polyamide 6 (PA-6) proves to be most suitable for electrospinning, since it can be electrospun under steady state conditions. In the membrane production process, formic acid and acetic acid in 1:1 concentration ratio is used as solvent with 16 wt\% PA- 6 concentration. The injection flow rate during the electrospinning process is $2 \mathrm{~mL} / \mathrm{h}$, the applied voltage is $20 \mathrm{kV}$ and the distance between needle and collector is $10 \mathrm{~cm}$. The resulting membrane consists of nanofibres with an average diameter of $140 \mathrm{~nm}$. It has a thickness of $120 \mu \mathrm{m}$, a mean pore size of $0.4 \mu \mathrm{m}$ and a density of $10 \mathrm{~g} / \mathrm{m}^{2}$. PA- 6 mass density is 1.14 g/ $\mathrm{cm}^{3}$ (Van De Velde and De Baets, 1997; Pashaei et al., 2011), which gives a surface area of $25 \mathrm{~m}^{2} / \mathrm{g}$, about one order of magnitude less than surface area of activated carbon. In previous research, the membrane was shown to have adsorptive properties towards water pollution, where slightly more adsorption occurs for thinner membranes (Daels et al., 2014). A typical SEM image is presented in Fig. 2. Recently, tensile properties of the membrane were evaluated, resulting in strain to failure of $36.6 \pm 5.7 \%$, stress at failure of $31.3 \pm 3.8 \mathrm{MPa}$ and Young's modulus of 111.4 $\pm 5.9 \mathrm{MPa}$ (De Schoenmaker, 2013).

\subsection{Ozone and $\mathrm{H}_{2} \mathrm{O}_{2}$ measurements}

Ozone in gas phase is measured with ozone monitor Envitec model 450. The detection principle is based on absorption of 


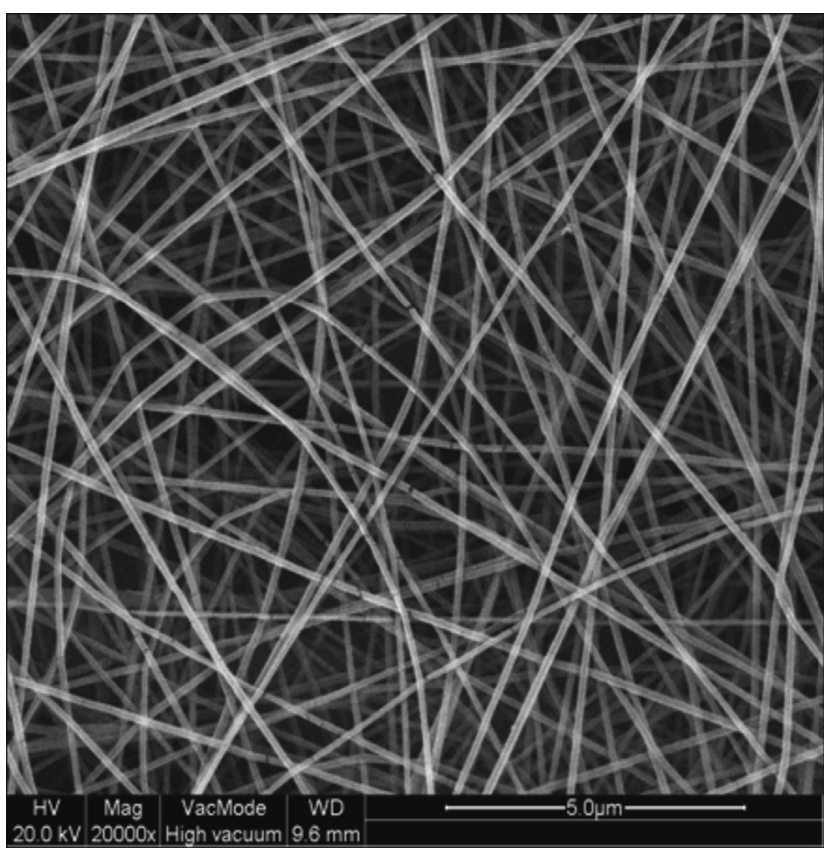

Fig. 2 - SEM image of nanofiber membrane of polyamide deposited on aluminum foil.

light at $253 \mathrm{~nm}$ in the absorption cell of the instrument. The monitor's limit of detection is $2 \mathrm{ppm}$ or $4.3 \mu \mathrm{g} / \mathrm{L}$ with error of $\mathrm{O}_{3}$ measurements not higher than $5 \%$. The concentration of hydrogen peroxide is determined by photometric method with metavanadate ammonium, as described by Nogueira et al. (2005). After adding $2.0 \mathrm{~mL}$ of sample to $0.8 \mathrm{~mL}$ of vanadate solution in acid medium, red-orange peroxovanadium cation is formed:

$\mathrm{VO}_{3}^{-}+4 \mathrm{H}^{+}+\mathrm{H}_{2} \mathrm{O}_{2} \rightarrow \mathrm{VO}_{2}^{3+}+3 \mathrm{H}_{2} \mathrm{O}$

The product of reaction (1) has an absorption maximum at $450 \mathrm{~nm}$. Hydrogen peroxide concentration can be estimated as:

$\mathrm{C}_{\mathrm{H}_{2} \mathrm{O}_{2}}=-\log _{10}\left(\frac{\mathrm{I}^{\text {sample }}}{\text { Itest }^{\text {tes }}}\right) \frac{\mathrm{V}_{2}}{283 \mathrm{~V}_{1}} \quad[\mathrm{~mol} / \mathrm{L}]$

where $I^{\text {sample }}$ and $I^{\text {test }}$ are the light intensities at a wavelength of $450 \mathrm{~nm}$ passing through the solution of metavanadate ammonium with and without adding the plasma-treated sample respectively. $V_{1}$ is the volume of the aliquot used for analysis $(\mathrm{mL})$ and $V_{2}$ is the final volume to which the aliquot $V_{1}$ is diluted $(\mathrm{mL})$ before the absorbance measurement. The statistic error of measurements is estimated about $5 \%$ for $\mathrm{H}_{2} \mathrm{O}_{2}$ concentration higher than $5 \mathrm{mmoL} / \mathrm{L}$ and $10 \%$ for lower concentration range.

\subsection{Micropollutant analysis}

\subsubsection{GC-MS technique}

Atrazine was extracted with an MPS-2 XYZ autosampler equipped with a headspace-solid phase microextraction unit (multi-PurposeSampler ${ }^{\circledR}$ or MPS ${ }^{\circledR}$, Gerstel ${ }^{\circledR}$, Mülheim and der Ruhr, Germany). For extraction, $19.00 \mathrm{~g}$ of the analyzed solution was hermetically sealed in $20 \mathrm{~mL}$ vials and incubated for $1 \mathrm{~min}$ at $50^{\circ} \mathrm{C}$ using agitation. Extraction of dissolved atrazine from the water matrix was done for $60 \mathrm{~min}$ at $50{ }^{\circ} \mathrm{C}$ using an SPME fiber $(100 \mu \mathrm{m}$ Polydimethylsiloxane (PDMS), fused silica fiber core, Supelco, USA). Organic molecules that adsorbed onto the fiber were separated and identified using an Agilent GC-MS (HP 6890 Series GC System, 5973 Mass Selective Detector) equipped with a cross-linked methyl silicone column (HP-PONA, $50 \mathrm{~m} \times 0.20 \mathrm{~mm}, 0.5 \mu \mathrm{m}$ film thickness; Agilent Technology) . For qualitative and quantitative measurements, the compounds were separated using Helium as the carrier gas (flow rate $\left.1 \mathrm{~mL} \min ^{-1}\right)$. The temperature gradient was $60{ }^{\circ} \mathrm{C}$ $(6 \mathrm{~min})$ to $280^{\circ} \mathrm{C}$ at $15^{\circ} \mathrm{C} \mathrm{min}{ }^{-1}$, held $11 \mathrm{~min}$. The injector and transfer lines were maintained isothermally at $250{ }^{\circ} \mathrm{C}$ and $280{ }^{\circ} \mathrm{C}$, respectively. The total ion current $(70 \mathrm{eV})$ was recorded in the mass range from 40 to 250 amu (scan mode) and an analysis time of $60 \mathrm{~min}$. Volatile compounds were identified by comparing the mass spectra obtained with the Wiley 275 library. Calibration of the detector was made with atrazine solutions of know concentration, from 1 to $100 \mu \mathrm{g} /$ L. The integrated atrazine peak was found to be linear with atrazine concentration in this range. All samples were measured in duplicate.

\subsubsection{HPLC-MS technique}

In order to determine the by-products of atrazine decomposition, solution samples before and after plasma treatment of 60 min were also analyzed with high-performance liquid chromatography-coupled to diode array UV detection and time of flight mass spectrometry (HPLC-MS). Before analysis, liquid-liquid extraction of $50 \mathrm{~mL}$ water samples was made in $5 \mathrm{~mL} \mathrm{CH} \mathrm{Cl}_{2}$ solvent with addition of $5 \mathrm{~mL}$ acetone and $1.2 \mathrm{~g} \mathrm{NaCl}$ in a similar way as described by Gong and Ye (1998). Separation of $3.2 \mathrm{~mL}$ was followed by evaporation to end volume of $1 \mathrm{~mL}$. For analysis, the procedure is similar to the one used by Boelaert et al. (2014) with an Agilent HPLC 1290 system consisting of a binary pump (Agilent Technologies, Waldbronn, Germany), a diode array detector (DAD) with a micro flow cell (volume: $1 \mu \mathrm{L}$, path length: $10 \mathrm{~mm}$ ) and a 6230 time-of-flight mass spectrometer (TOF-MS) equipped with a Jetstream Electrospray Ionization source (ESI). Separations were performed on a Zorbax C18 HPLC column $(15 \mathrm{~cm} \times 2.1 \mathrm{~mm} \times 5 \mu \mathrm{m})$ equipped with a $2 \mathrm{~mm}$ C18 pre-column (SecurityGuard cartridge, Phenomenex). The mobile phase composition has been prepared as follows: $\mathrm{A}: \mathrm{H}_{2} \mathrm{O}+0.1 \%$ formic acid and $\mathrm{B}$ : Acetonitrile $+0.1 \%$ formic acid. A flow rate of $200 \mu \mathrm{L} / \mathrm{min}$ was used whereby initial conditions containing $2 \%$ B were held constant during $5 \mathrm{~min}$, followed by a gradient up to $100 \% \mathrm{~B}$ in $50 \mathrm{~min}$, a plateau of $100 \%$ during $10 \mathrm{~min}$ and back to initial in $2 \mathrm{~min}$. In between analyses, the column was conditioned during $15 \mathrm{~min}$.

The system was operated with the Agilent Masshunter software for instrument control and data acquisition. UV absorbance values were measured at $254 \mathrm{~nm}$ with a data acquisition rate of $20 \mathrm{~Hz}$. The injection volume was $5 \mu \mathrm{L}$ and all experiments were conducted at a temperature of $20^{\circ} \mathrm{C}$. TOFMS detection was performed in the positive ionization mode. Mass ranges from 50 to 1000 amu were scanned. All 
tests were carried out in duplicate with a regular blank solvent analysis to ensure absence of cross contamination.

\section{Experimental results and discussion}

\subsection{Power calculation}

Typical waveforms of the applied voltage and current of the pulsed DBD plasma are shown in Fig. 3. The applied voltage $\mathrm{V}_{a}$ and current $\mathrm{I}_{\mathrm{on}}$ in Fig. 3 are measured during plasma generation. The displacement current $I_{\text {off }}$ is obtained at the same applied voltage when plasma is off. It does not represent a current of moving charges, as it is only caused by a time-varying electric field. Since the displacement current does not contribute to the part of the energy dissipated in the discharge, the actual discharge current $I_{\text {dis }}$ in the plasma is obtained by subtracting the displacement current $I_{\text {off }}$ from the total current $I_{\text {on. }}$. In Fig. 3, a discharge current pulse of $7 \mathrm{~A}$ with duration of $20 \mathrm{~ns}$ occurs $20 \mathrm{~ns}$ after rise of the voltage to its maximum. Discharge power is calculated as $\int_{t} V_{a}(t) I_{d i s}(t) d t$ whereas total input power of the pulsed generator is given by $\int_{t} V_{a}(t) I_{o n}(t) d t$. This way, applied
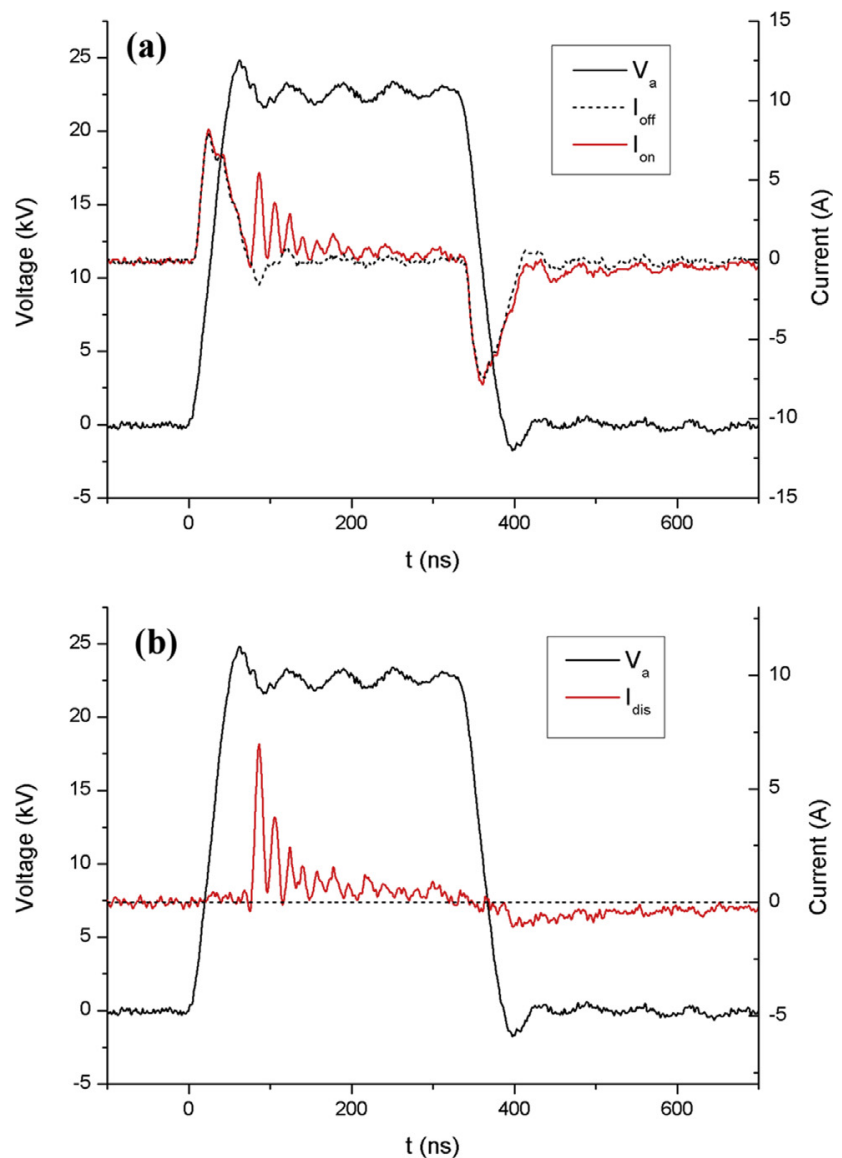

Fig. 3 - a) Waveform of the applied voltage $V_{a}$ and current $I_{\text {on }}$ in the case of plasma generation and displacement current $I_{\text {off }}$ in the case without plasma generation. b) Waveform of the applied voltage and discharge current $I_{\text {dis }}$ after subtracting the displacement current. power and discharged power are determined to be $2.0 \pm 0.1 \mathrm{~W}$ and $1.7 \pm 0.1 \mathrm{~W}$ respectively.

\subsection{Spectral analysis}

As seen in Fig. 4, the emission spectrum of the discharge is dominated by radiative relaxation of excited vibrational states of the $\mathrm{N}_{2}$ molecule, indicating the presence of metastable $\mathrm{N}_{2}$ molecules. As pointed out by Choi et al. (2006), metastable states of $\mathrm{N}_{2}$ formed in air plasma are involved in formation of $\mathrm{O}$ and $\mathrm{O}_{3}$. First, oxygen atoms are formed through the following reactions:

$\mathrm{N}_{2}+\mathrm{e} \rightarrow \mathrm{N}_{2}^{*}+\mathrm{e}$

$\mathrm{N}_{2}^{*}+\mathrm{O}_{2} \rightarrow \mathrm{N}_{2}+2 \mathrm{O}$

$\mathrm{N}_{2}^{*}+\mathrm{O}_{2} \rightarrow \mathrm{N}_{2} \mathrm{O}+\mathrm{O}$

Next, ozone is generated from a three body reaction as:

$\mathrm{O}+\mathrm{O}_{2}+\mathrm{M} \rightarrow \mathrm{O}_{3}+\mathrm{M}$

where $\mathrm{M}=\mathrm{O}_{2}$ or $\mathrm{N}_{2}$ is a third collision partner. Atomic oxygen can also be generated by electron impact on an oxygen molecule:

$\mathrm{O}_{2}+\mathrm{e}^{*} \rightarrow \mathrm{O}+\mathrm{O}+\mathrm{e}$

Despite the presence of atomic oxygen in the plasma, emission lines of excited oxygen atoms are very small, such as the $\mathrm{O}^{\mathrm{I}}$ triplet at $777.5 \mathrm{~nm}$ for example. The $\mathrm{OH}(\mathrm{A}-\mathrm{X})(0,0) \mathrm{Q}$ band head around $309 \mathrm{~nm}$ and the $\mathrm{OH}(\mathrm{A}-\mathrm{X})(1,1)$ band around $315 \mathrm{~nm}$ are overlapped with the $\mathrm{N}_{2}{ }^{*}$ bands and are therefore not observed in the spectrum. Nevertheless, the small OH(A$\mathrm{X})(0,0) \mathrm{R}$-band head around $307 \mathrm{~nm}$ indicates the presence of excited $\mathrm{OH}$ radicals. $\mathrm{OH}$ radicals can be formed in plasma through many reactions, which typically require the presence of water molecules, as discussed in two recent excellent

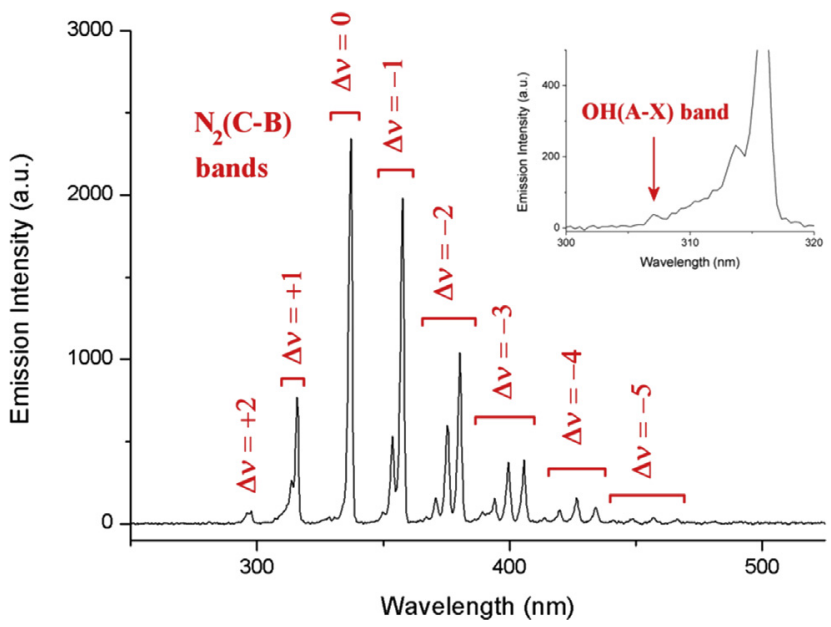

Fig. 4 - Space and time averaged emission spectrum of the discharge measured with resolution of $1.3 \mathrm{~nm} \Delta v$ represents the change in quantum number $\nu$ of each radiative transition in the $\mathrm{N}_{2}(\mathrm{C}-\mathrm{B})$ band system. This band system indicates the presence of metastable $\mathrm{N}_{2}$ molecules. 
reviews by Locke and Shih (2011) and Jiang et al. (2014). Dissociation of water by electron impact is the primary example:

$\mathrm{H}_{2} \mathrm{O}+\mathrm{e} \rightarrow \mathrm{OH}+\mathrm{H}+\mathrm{e}$

Also, vibrational and rotational excitation of a water molecule can lead to $\mathrm{OH}$ radical formation:

$$
\begin{aligned}
& \mathrm{H}_{2} \mathrm{O}+\mathrm{e} \rightarrow \mathrm{H}_{2} \mathrm{O}^{*}+\mathrm{e} \\
& \mathrm{H}_{2} \mathrm{O}^{*}+\mathrm{H}_{2} \mathrm{O} \rightarrow \mathrm{H}_{2} \mathrm{O}+\mathrm{H}+\mathrm{OH} \\
& \mathrm{H}_{2} \mathrm{O}^{*}+\mathrm{H} \rightarrow \mathrm{H}_{2}+\mathrm{OH}
\end{aligned}
$$

The presence of atomic oxygen boosts $\mathrm{OH}$ radical formation as well:

$\mathrm{O}+\mathrm{H}_{2} \mathrm{O} \rightarrow 2 \mathrm{OH}$

It has to be noted that $\mathrm{OH}$ radicals have a lifetime in the order of 10-100 $\mu$ s in gas phase (Locke and Shih, 2011). Therefore, only $\mathrm{OH}$ radicals that are generated near the water surface can diffuse from the plasma zone into the surrounding water. Their lifetime in the liquid phase is in the nanosecond range, since they will react immediately with a surrounding molecule due to their high reactivity. This way, they can recombine to a long-lived hydrogen peroxide molecule through following reactions:

$\mathrm{OH}+\mathrm{H}_{2} \mathrm{O}^{*} \rightarrow \mathrm{H}_{2} \mathrm{O}_{2}+\mathrm{H}$

$\mathrm{OH}+\mathrm{OH} \rightarrow \mathrm{H}_{2} \mathrm{O}_{2}$

The latter two reactions can also occur in the gas phase, after which the hydrogen peroxide molecules can diffuse into the surrounding water. Generation of UV photons, $\mathrm{N}_{2}$ metastables, atomic $\mathrm{O}, \mathrm{OH}$ radicals and $\mathrm{O}_{3}$ in gas phase indicates that pDBD is indeed an effective source of active species for advanced oxidation of micropollutants in water.

\subsection{Ozone and $\mathrm{H}_{2} \mathrm{O}_{2}$ production}

$\mathrm{O}_{3}$ concentration in gas phase is about $153 \mathrm{ppm}$ or $327 \mu \mathrm{g} / \mathrm{L}$ with nanofiber membrane in the setup and $163 \mathrm{ppm}$ or $349 \mu \mathrm{g} /$ $\mathrm{L}$ without membrane. Taking into account the accuracy of the ozone monitor, ozone production is thus independent of the presence of the membrane. This agrees with our expectations, since ozone formation through reactions (3)-(7) occurs in the gas phase, which is screened off from the membrane by the water film under treatment.

$\mathrm{H}_{2} \mathrm{O}_{2}$ concentration in the liquid phase is shown in function of treatment time in Fig. $5 . \mathrm{H}_{2} \mathrm{O}_{2}$ production is about $5 \%$ higher when the nanofiber membrane is added into the setup. This difference is in the range of experimental error in measurements of the discharge power which is about $5 \%$. Therefore, $\mathrm{H}_{2} \mathrm{O}_{2}$ production is considered to be independent of the presence of the membrane as well, for similar reasons as those for ozone production. From these results, an energy yield for ozone generation of $5.07 \mathrm{~g} / \mathrm{kWh}$ and for hydrogen peroxide generation of $0.23 \mathrm{~g} / \mathrm{kWh}$ is calculated, from $2.0 \mathrm{~W}$ applied power, 0.5 SLM gas flow rate and $100 \mathrm{~mL}$ total solution volume. According to the review of Locke and Shih (2011),

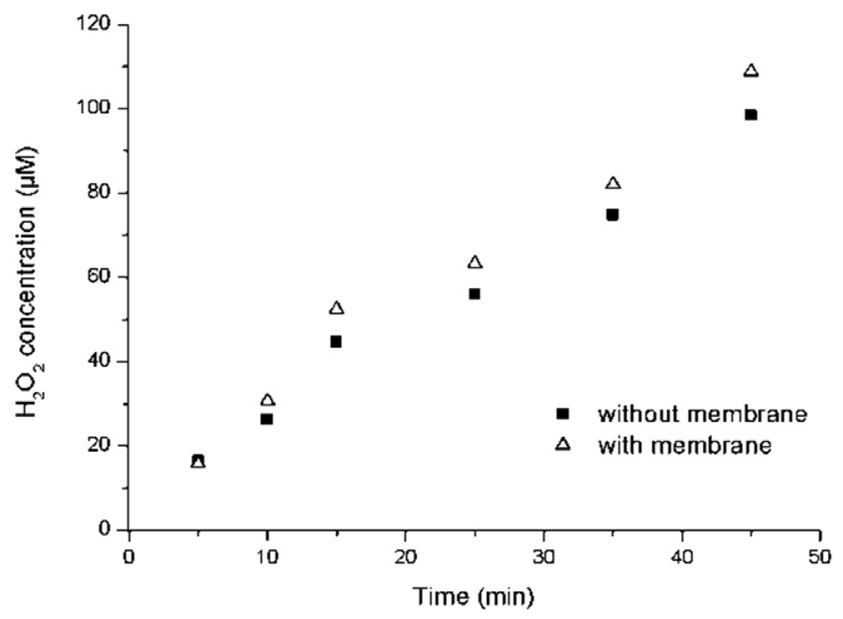

Fig. 5 - Hydrogen peroxide production in the liquid phase in function of time with and without presence of the nanofiber membrane.

reactors based on discharge over a liquid surface have reported $\mathrm{H}_{2} \mathrm{O}_{2}$ yields ranging from 0.04 to $5.0 \mathrm{~g} / \mathrm{kWh}$, with most data falling below $1 \mathrm{~g} / \mathrm{kWh}$. The $\mathrm{H}_{2} \mathrm{O}_{2}$ yield for plasma systems is limited by mass transfer and the size of the plasma-liquid interface, where a larger plasma-liquid interface is an advantage in $\mathrm{pDBD}$.

\subsection{Energy efficiency for atrazine removal}

Efficiency of atrazine removal is measured by GC-MS method with solid-liquid extraction. According to GC-MS analysis, $45 \mathrm{~min}$ of plasma treatment reduces the initial atrazine concentration from $30.0 \mu \mathrm{g} / \mathrm{L}$ to $11.7 \mu \mathrm{g} / \mathrm{L}$ and $4.6 \mu \mathrm{g} /$ $\mathrm{L}$, respectively in absence and in presence of the nanofiber membrane. The increase of atrazine decomposition in the reactor with nanofiber membrane can be explained by adsorption of atrazine on the membrane. Adsorption increases the local concentration of the pollutant near the plasma-liquid interface, leading to more effective reaction of active plasma species with pollutant in the plasma-liquid interface. Since this effect only enhances atrazine decomposition in the thin water film near the active plasma region (about $0.1 \%$ of the total solution volume), the dominating decomposition processes are taking place at the plasma-liquid interface.

Hijosa-Valsero et al. (2013) investigated atrazine decomposition by DBD discharge at much higher initial concentration $(5 \mathrm{mg} / \mathrm{L})$. The authors observed an exponential decay of atrazine concentration during treatment. This allows to determine a first order reaction rate constant $k_{\mathrm{A}}$ for atrazine removal in our reactor from the equation.

$\ln \left(\frac{C_{0}}{C_{t}}\right)=k_{A} t$

where $C_{0}$ and $C_{t}$ are the atrazine concentration of the initial solution and end solution respectively and $t=2700 \mathrm{~s}$ (=45 $\mathrm{min}$ ) is the total treatment time. Energy yield $\mathrm{G}_{50}$ in $\mathrm{g} / \mathrm{kWh}$ for $50 \%$ atrazine removal is determined from $k_{\mathrm{A}}$ as (Hijosa-Valsero et al., 2013) 
$G_{50}=\frac{1}{2} \frac{k_{A} C_{0} V}{P \ln 2} 3.6 \times 10^{6} \mathrm{~J} / \mathrm{kWh}$

where $\mathrm{V}$ is the solution volume, $\mathrm{P}=2.0 \mathrm{~W}$ is the input power and initial concentration $\mathrm{C}_{0}$ is given in $\mathrm{g} / \mathrm{L}$. Resulting values for $k_{\mathrm{A}}$ and $\mathrm{G}_{50}$ are found in Table 2.

In order to confirm that atrazine decomposition is taking place mostly at the plasma-liquid interface, the effect of the dominant degradation processes in the water bulk is estimated. According to the general view in literature, direct oxidation by ozone and oxidation by the dark peroxone process are the most dominant oxidation processes in the water bulk in absence of UV light (Hong et al., 1996). Atrazine degradation due to direct oxidation by ozone can be determined with the formula.

$$
-\frac{d[\mathrm{~A}]}{d t}=k_{\mathrm{A}, \mathrm{O}_{3}}[\mathrm{~A}]\left[\mathrm{O}_{3}\right]
$$

where $[\mathrm{A}]$ and $\left[\mathrm{O}_{3}\right]$ is the molar concentration of atrazine and ozone respectively and $k_{\mathrm{A}, \mathrm{O}_{3}}=6.0 \mathrm{M}^{-1} \mathrm{~s}^{-1}$ is the reaction rate constant of direct oxidation of atrazine by $\mathrm{O}_{3}$. Maximal $\mathrm{O}_{3}$ concentration in water is reached in thermodynamic equilibrium according to Henry's law. Henry's law constant $\mathrm{H}_{0}$ for ozone in water at $20^{\circ} \mathrm{C}$ is reviewed by Kuosa (2008) in function of $\mathrm{pH}$, using several values in literature and from simulation. Based on this review, the constant is taken as $\mathrm{H}_{\mathrm{O}}=7.9 \times 10^{3} \mathrm{kPa} \mathrm{M}^{-1}$ at $\mathrm{pH}=5$ and $\mathrm{H}_{0}=7.3 \times 10^{3} \mathrm{kPa} \mathrm{M}^{-1}$ at $\mathrm{pH}=4$, with a linear dependence on $\mathrm{pH}$. For our experiments with initial $\mathrm{pH}=5.06$ and final $\mathrm{pH}=3.99$, this gives an initial and final dissolved ozone concentration $\left[\mathrm{O}_{3}\right]$ of $2.03 \mu \mathrm{M}$ and $2.19 \mu \mathrm{M}$ respectively. This way, atrazine concentration $[\mathrm{A}]$ is calculated based on Eq. (17) where $\mathrm{pH}$ (and thus also $\left[\mathrm{O}_{3}\right]$ ) changes linearly in time.

A second process responsible for atrazine decomposition in the bulk is oxidation by peroxone. This process occurs when hydrogen peroxide is added to ozonated water. In that case, $\mathrm{OH}$ radicals are formed in liquid phase through the reactions (18) to (21)

$$
\begin{aligned}
& \mathrm{H}_{2} \mathrm{O}_{2} \rightleftharpoons \mathrm{H}^{+}+\mathrm{HO}_{2}^{-} \\
& \mathrm{O}_{3}+\mathrm{HO}_{2}^{-} \rightarrow \mathrm{O}_{3}^{-}+\mathrm{HO}_{2} \\
& \mathrm{O}_{3}^{-} \rightleftharpoons \mathrm{O}_{2} \rightarrow \mathrm{O}^{-} \\
& \mathrm{O}^{-}+\mathrm{H}_{2} \mathrm{O} \rightarrow \mathrm{OH}^{-}+\mathrm{OH}
\end{aligned}
$$

Since the reaction of $\mathrm{O}_{3}$ is much faster with the perhydroxyl anion $\mathrm{HO}_{2}^{-}$than with the conjugate acid $\mathrm{H}_{2} \mathrm{O}_{2}$, reactions (18) to (21) become the dominant source of $\mathrm{OH}$ radicals during the peroxone process in the absence of UV light (Hong et al., 1996). As should be noted, the overall production rate of $\mathrm{OH}$ radicals is influenced by scavenging reactions (22) and (23).

$\mathrm{OH}+\mathrm{O}_{3} \rightarrow \mathrm{HO}_{2}+\mathrm{O}_{2}$

$\mathrm{OH}+\mathrm{H}_{2} \mathrm{O}_{2} \rightarrow \mathrm{HO}_{2}+\mathrm{H}_{2} \mathrm{O}$

Similarly to Eq. (17), atrazine degradation due to the peroxone process is given by.

$$
-\frac{d[\mathrm{~A}]}{d \mathrm{t}}=k_{\mathrm{A}, \mathrm{OH}}[\mathrm{A}][\mathrm{OH}]
$$

where $[\mathrm{OH}]$ is the molar concentration of $\mathrm{OH}$ radicals and $k_{\mathrm{A}, \mathrm{OH}}=3 \times 10^{9} \mathrm{M}^{-1} \mathrm{~s}^{-1}$ is the reaction rate constant of atrazine oxidation by $\mathrm{OH}$ radicals (Fischbacher et al., 2013). For peroxone process, the pseudo-steady-state concentration of $[\mathrm{OH}]$ can be calculated with the kinetic model of Hong et al. (1996) as

$$
[\mathrm{OH}]_{\mathrm{ss}}=\frac{1.2 k_{19}\left[\mathrm{O}_{3}\right]\left[\mathrm{H}_{2} \mathrm{O}_{2}\right]_{\mathrm{T}} \mathrm{K}_{18}\left[\mathrm{H}^{+}\right]^{-1}}{k_{22}\left[\mathrm{O}_{3}\right]+k_{23}\left[\mathrm{H}_{2} \mathrm{O}_{2}\right]_{\mathrm{T}}+k_{\mathrm{A}, \mathrm{OH}}[\mathrm{A}]}
$$

where $k_{19}=2.8 \times 10^{6} \mathrm{M}^{-1} \mathrm{~s}^{-1}, k_{22}=1.1 \times 10^{8} \mathrm{M}^{-1} \mathrm{~s}^{-1}$ and $k_{23}=2.7 \times 10^{7} \mathrm{M}^{-1} \mathrm{~s}^{-1}$ are reaction rate constants from reactions (19), (22) and (23) respectively, $\mathrm{K}_{18}=2.4 \times 10^{-12}$ is the equilibrium constant of reaction (18) and $\left[\mathrm{H}_{2} \mathrm{O}_{2}\right]_{\mathrm{T}}$ and $\left[\mathrm{H}^{+}\right]$are the molar concentration of hydrogen peroxide and the hydrogen cation. In Formula (25), the $\mathrm{OH}$ radical formation yield reduction of $40 \%$ as suggested by Fischenbacher et al. (2013) is taken into account. Scavengers of the $\mathrm{OH}$ radical, other than $\mathrm{O}_{3}, \mathrm{H}_{2} \mathrm{O}_{2}$ and atrazine, are disregarded, since the goal is to estimate the maximal degradation of atrazine by the peroxone process. Kinetics of atrazine decomposition due to direct oxidation by $\mathrm{O}_{3}$ in combination with peroxone process is presented in Fig. 6.

Simulation gives an atrazine degradation of $3.4 \%, 10.4 \%$ and $13.5 \%$ after $45 \mathrm{~min}$ of treatment, respectively by direct oxidation with ozone, by the peroxone process and by the combination of both. Fig. 6 shows concentration of atrazine and $[\mathrm{OH}]$ in function of treatment time as simulated for the different processes. Initially, $\mathrm{OH}$ radical formation by the peroxone process increases strongly, to reach its peak value of $2.13 \times 10^{-14} \mathrm{M}$ after $9.8 \mathrm{~min}$. After the peak, scavenging of $\mathrm{OH}$ radicals by $\mathrm{H}_{2} \mathrm{O}_{2}$ becomes dominant and decreases the efficiency of the peroxone process. This is a well-known phenomenon, since the most optimal $\left[\mathrm{H}_{2} \mathrm{O}_{2}\right]$ to $\left[\mathrm{O}_{3}\right]$ ratio

\begin{tabular}{|c|c|c|c|c|c|}
\hline Parameter & Without membrane & Membrane & Direct oxidation by $\mathrm{O}_{3}$ & Oxidation by peroxone & Theoretical limit \\
\hline$c_{\mathrm{A}, 45 \min }(\mu \mathrm{g} / \mathrm{L})$ & 11.7 & 4.6 & 29.0 & 26.9 & $7.6 \times 10^{-3}$ \\
\hline $\mathrm{y}_{-\mathrm{A}}(\%)$ & 61.0 & 84.7 & 3.4 & 10.4 & 99.97 \\
\hline$k_{\mathrm{A}}\left(\mathrm{s}^{-1}\right)$ & $3.5 \times 10^{-4}$ & $6.9 \times 10^{-4}$ & $1.3 \times 10^{-5}$ & $4.1 \times 10^{-5}$ & $3.1 \times 10^{-3}$ \\
\hline $\mathrm{G}_{50}(\mathrm{~g} / \mathrm{kWh})$ & $1.4 \times 10^{-3}$ & $2.7 \times 10^{-3}$ & $5.1 \times 10^{-5}$ & $1.6 \times 10^{-4}$ & $1.2 \times 10^{-2}$ \\
\hline
\end{tabular}
value for peroxone mentioned in literature is typically

Table 2 - Final atrazine concentration $c_{\mathrm{A}, 45 \mathrm{~min}}$, atrazine degradation yield $\mathrm{y}_{-\mathrm{A}}$ and first order reaction rate constant $k_{\mathrm{A}}$ for atrazine decomposition with initial concentration of $30 \mu \mathrm{g} / \mathrm{L}$. Energy yield is presented as $\mathbf{G}_{50}$ value corresponding to $50 \%$ atrazine decomposition. Experimental data (in bold) without and with nanofiber membrane are retrieved from GC-MS measurements. Data for direct oxidation by $\mathrm{O}_{3}$, for oxidation by peroxone process and the theoretical limit of the reactor are results of simulation based on formulas (17), (24), (25) and (26). 


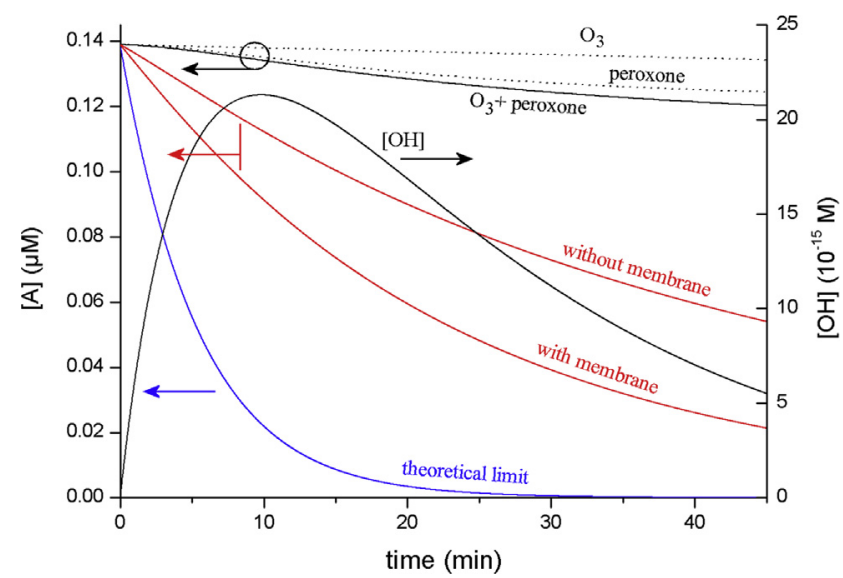

Fig. 6 - Atrazine and $\mathrm{OH}$ radical concentration in function of treatment time for direct oxidation with ozone $\left(\mathrm{O}_{3}\right)$, for dark peroxone process and for combination of both, as calculated with the kinetic model of Hong et al. (1996) from formulas (17), (24) and (25). The theoretical limit is calculated from formula (26), while taking into account the peroxone process with direct ozonation in the bulk solution. The red curves are calculated from $10 \%$ to $21 \%$ of atrazine removal at the outlet in combination with the bulk processes and correspond with the experiments without and with membrane respectively. Since the red curves are much lower than the combined ozone and peroxone curve, oxidation by ozone and peroxone only contributes to a small part of total atrazine removal. (For interpretation of the references to color in this figure legend, the reader is referred to the web version of this article.)

ranging from 0.3 to 1.0 (Glaze et al., 1987; Munter, 2001; Hsu et al., 2003; De Witte et al., 2009; Kalra et al., 2011).

Table 2 presents a summary of data on atrazine decomposition in the reactor, obtained from experiments and from formulas (17), (24) and (25). Also, a theoretical limit of the reactor efficiency was calculated from the Equation (26). This formula is based on the assumptions of complete atrazine decomposition at the outlet of the reactor chamber during pumping and of ideal mixing of the solution at the inlet.

$$
-\frac{d[A]}{d t}=\frac{Q}{V}[A]
$$

where $Q=0.3 \mathrm{~mL} / \mathrm{s}(=18 \mathrm{~mL} / \mathrm{min})$ is the water flow and $\mathrm{V}=100 \mathrm{~mL}$ is the total solution volume. To be complete, atrazine degradation by peroxone and ozone in the solution bulk is taken into account in this theoretical limit.

The atrazine removal energy yield in the experiments and in the red curves in Fig. 6 is one order of magnitude lower than the theoretical limit. More specifically, $10 \%$ and $21 \%$ of atrazine concentration that passes along the active plasma zone and leaves the reactor chamber during pumping is removed without membrane and with membrane respectively, as determined by our simulations. As discussed before, this effect of the membrane indicates the importance of degradation processes in the proximity of the plasma-liquid interface. Direct oxidation by ozone and oxidation by the peroxone process can only explain about $20 \%$ of the observed atrazine decomposition without membrane. This is a further indication that oxidative processes in the thin water film play an important role. Atrazine decomposition at the plasma-liquid interface is caused by multiple reactive plasma species from the active plasma zone, such as UV photons, radicals, ions and long-living metastables like $\mathrm{HO}_{2}^{*}$. When these species reach the water surface and interact with atrazine, oxidation takes place. Increasing the local concentration of atrazine near the plasma-liquid interface will increase the chance on such collisions and thus the overall atrazine degradation yield, which is a strong advantage of the suggested method.

\subsection{By-products}

HPLC-MS chromatograms of the initial solution and the solution after 45 min of plasma treatment are shown in Fig. 7. In agreement with the GC-MS results, a stronger decrease of the atrazine peak is observed after treatment when the nanofiber membrane is added in the setup. Due to the low initial atrazine concentration, however, accurate detection of most byproducts by HPLC-MS is not possible. At least 4 oxidation products have been found with monoisotopic mass $128.04 \mathrm{Da}$, 170.14 Da, 187.06 $\mathrm{Da}$ and 213.08 Da, which all have higher abundance when the membrane is added in the setup. Only two of them are tentatively identified as deethylatrazine and ammelide (Fig. 8). Both are commonly found amongst atrazine by-products in advanced oxidation processes (Adams and Randtke, 1992; Gonzalez et al., 1994). Deethylatrazine is one of the first generation intermediates in several atrazine degradation pathways proposed in literature. Moreover, it is considered to be more stable than other intermediates from the first generation, due to its persistence in natural waters and due to the higher reactivity of the ethyl group (Adams and Randtke, 1992; Beltrán et al., 1996). Ammelide is one of the final stable products in the atrazine oxidation pathway and is considered to be less toxic than atrazine and its earlier intermediates (Gonzalez et al., 1994; Beltrán et al., 1996; Chan et al., 2004; Khan et al., 2014; Xu et al., 2014). The relative stability of both intermediates explains why they are detected in the present study despite the low initial atrazine concentration.

To our knowledge, atrazine degradation by-products from treatment with DBD plasma have only been reported by Hijosa-Valsero et al. (2013). The authors used a DBD reactor very similar to the one used in this study, but powered by AC high voltage and with much higher initial atrazine concentration of $5 \mathrm{mg} / \mathrm{L}$ Hijosa-Valsero et al. (2013) identified 3 common atrazine oxidation products, deethylatrazine, deisopropylatrazine and atrazine amide, and one less common intermediate 4-chloro-6-(ethenylamino)-1,3,5-triazin-2-yl. After $84 \%$ of atrazine decomposition, the deethylatrazine to atrazine relative abundance in the mass spectra was roughly 0.5 , while it is 0.02 in the present study in presence of the nanofiber membrane. Hoeben (2000) investigated degradation of a $25 \mathrm{mg} / \mathrm{L}$ atrazine solution by corona discharge above water and detected at least 7 oxidation products, but could not identify them. As this suggests, the degradation pathway of atrazine under plasma treatment is sensitive to different experimental parameters.

The HPLC-MS results of the present study illustrate the high potential of pDBD plasma to decompose persistent 


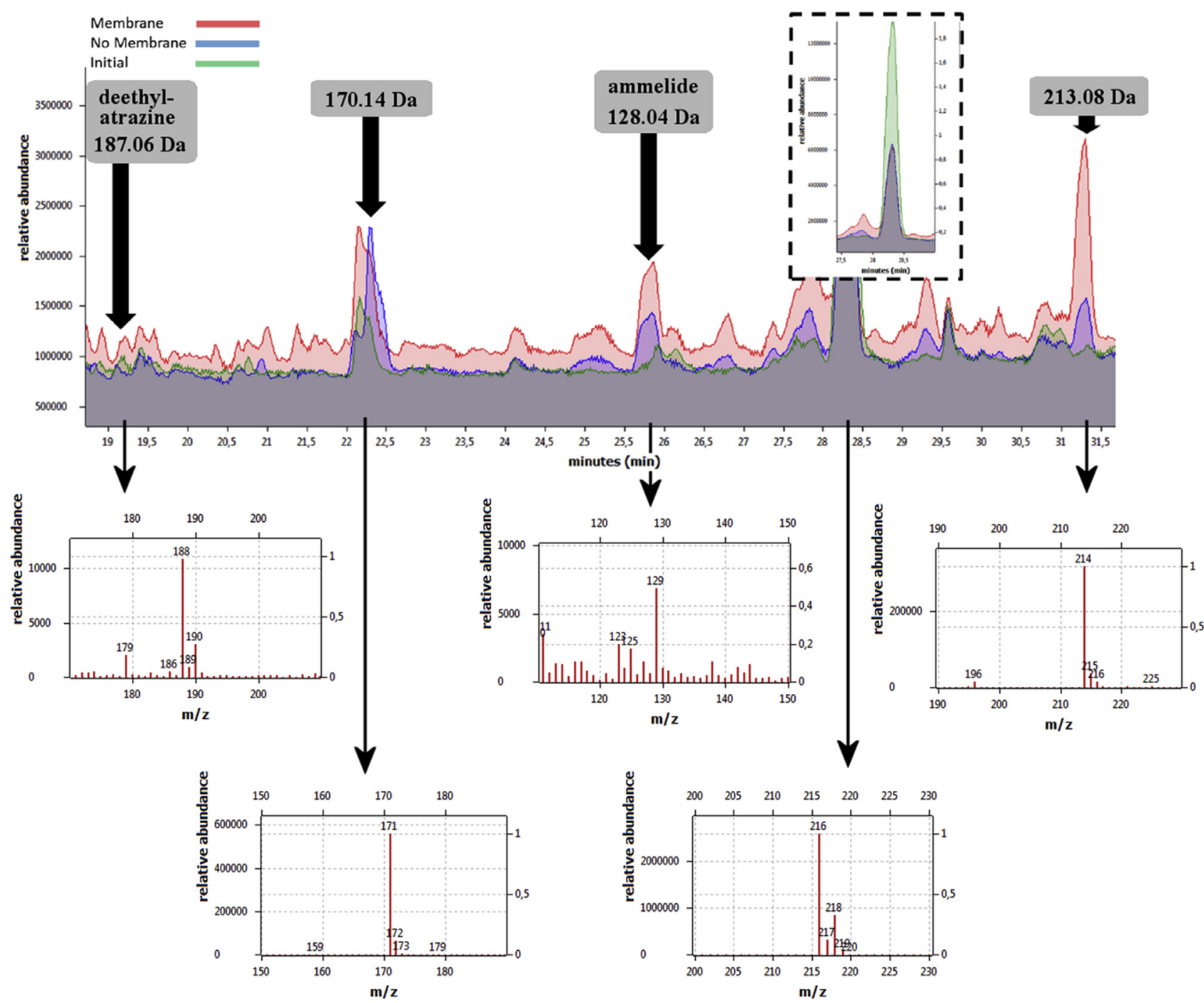

Fig. 7 - Detail (from $18.7 \mathrm{~min}$ to $31.7 \mathrm{~min}$ ) of HPLC-MS chromatogram of initial atrazine solution and of treated samples with and without the presence of the nanofiber membrane. For each considered peak belonging to an oxidation by-product, the mass spectrum is shown.

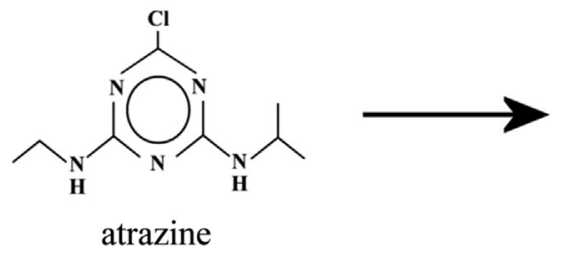<smiles>CC(C)Nc1nc(N)nc(Cl)n1</smiles>

deethylatrazine<smiles>Nc1nc(O)nc(O)n1</smiles>

ammelide

Fig. 8 - Proposed oxidation by-products of atrazine treatment with pulsed DBD.

micropollutants. Moreover, as can be seen from the different peaks in Fig. 7, adding the nanofiber membrane in the setup enhances by-product generation. Cleavage of the s-triazine ring has not yet been reported in any advanced oxidation process (Mededovic and Locke, 2007). Pelizzetti et al. (1990) have concluded from detailed GC-MS analysis that photocatalytic oxidation of aqueous atrazine cannot destroy the triazine ring and that the final oxidation product is cyanuric acid.

\section{Conclusion}

In this work, a new water treatment reactor based on atmospheric pulsed dielectric barrier discharge above water is investigated. In order to increase decomposition efficiency and to limit unwanted by-product formation, combination of pDBD plasma with adsorption on nanofiber membrane was proposed. Atrazine is chosen as model micropollutant with 
an initial concentration of $30 \mu \mathrm{g} / \mathrm{L}$, which is one order of magnitude higher than the maximally allowed concentration in drinking water. In the pDBD reactor, the measured energy yield of $\mathrm{H}_{2} \mathrm{O}_{2}$ production in liquid phase is about $0.23 \mathrm{~g} / \mathrm{kWh}$ and concentration of $\mathrm{H}_{2} \mathrm{O}_{2}$ is linearly dependent on treatment time. The energy yield of $\mathrm{O}_{3}$ production is measured to be $5.07 \mathrm{~g} / \mathrm{kWh}$. While the $\mathrm{H}_{2} \mathrm{O}_{2}$ and $\mathrm{O}_{3}$ production in the reactor is not influenced by the presence of the nanofiber membrane, there is a significant increase in atrazine decomposition when the membrane is added to the setup. An atrazine removal yield of $85 \%$ can be obtained with nanofiber membrane at $45 \mathrm{~min}$ of treatment where only about $61 \%$ removal is reached with plasma alone. The observed effect is caused by atrazine adsorption on the membrane close to the plasma active region, leading to a higher local atrazine concentration near the plasma-liquid interface. The higher local concentration increases the frequency of direct and indirect oxidizing interactions of the micropollutant with reactive species from the active plasma region. To reinforce this explanation, the contribution of the dominant atrazine degradation processes in the water bulk has been estimated. According to literature, direct oxidation by ozone and oxidation by peroxone are the dominant processes in the water bulk in absence of UV light. Using the kinetic model of Hong et al. (1996), the contribution of these bulk processes to the overall atrazine degradation is calculated to be only about $20 \%$. Therefore, the determining oxidation reactions are occurring in the thin water layer near the plasma active region. The main by-products of atrazine decomposition measured by HPLC-MS are the first generation intermediate deethylatrazine and the deep oxidation by-product ammelide. System efficiency is almost doubled when the nanofiber membrane is placed in the plasma reactor with deeper degradation of atrazine to the byproducts. These results show the benefits of combining non-thermal plasma with pollutant adsorption for degradation of micropollution, a synergetic effect that yet has to receive more attention.

\section{R E F E R E N C E S}

Adams, C.D., Randtke, S.J., 1992. Ozonation byproducts of atrazine in synthetic and natural waters. Environ. Sci. Technol. 26 (11), 2218-2227. http://dx.doi.org/10.1021/ es00035a022.

Beltrán, F.J., González, M., Rivas, F.J., Alvarez, P., 1996. Aqueous $\mathrm{UV}$ radiation and $\mathrm{UV} / \mathrm{H}_{2} \mathrm{O}_{2}$ oxidation of atrazine first degradation products: deethylatrazine and deisopropylatrazine. Environ. Toxicol. Chem. 15 (6), 868-872. http://dx.doi.org/10.1002/etc.5620150607.

Benetoli, L.O., Cadorin, B.M., Baldissarelli, V.Z., Geremias, R., de Souza, I.G., Debacher, N.A., 2012. Pyrite-enhanced methylene blue degradation in non-thermal plasma water treatment reactor. J. Hazard. Mater. 237, 55-62. http://dx.doi.org/10.1016/ j.jhazmat.2012.07.067.

Bobkova, E.S., Grinevich, V.I., Ivantsova, N.A., Rybkin, V.V., 2012. A study of sulfonol decomposition in water solutions under the action of dielectric barrier discharge in the presence of different heterogeneous catalysts. Plasma Chem. Plasma Process. 32 (1), 97-107. http://dx.doi.org/10.1007/s11090-011-9326-z.

Boelaert, J., t'Kindt, R., Schepers, E., Jorge, L., Glorieux, G., Neirynck, N., Lynen, F., Sandra, K., 2014. State-of-the-art nontargeted metabolomics in the study of chronic kidney disease. Metabolomics 10 (3), 425-442. http://dx.doi.org/10.1007/ s11306-013-0592-z.

Bolong, N., Ismail, A., Salim, M., Matsuura, T., 2009. A review of the effects of emerging contaminants in wastewater and options for their removal. Desalination 239 (1-3), 229-246. http://dx.doi.org/10.1016/j.desal.2008.03.020.

Bruggeman, P., Leys, C., 2009. Non-thermal plasmas in and in contact with liquids. J. Phys. D: Appl. Phys. 42 (5), 053001. http://dx.doi.org/10.1088/0022-3727/42/5/053001.

Chan, C.Y., Tao, S., Dawson, R., Wong, P.K., 2004. Treatment of atrazine by integrating photocatalytic and biological processes. Environ. Pollut. 131 (1), 45-54. http://dx.doi.org/ 10.1016/j.envpol.2004.02.022.

Choi, J.H., Han, I., Baik, H.K., Lee, M.H., Han, D.-W., Park, J.-C., Lee, I.-S., Song, K.M., Lim, Y.S., 2006. Analysis of sterilization effect by pulsed dielectric barrier discharge. J. Electrost. 64 (1), 17-22. http://dx.doi.org/10.1016/j.elstat.2005.04.001.

Daels, N., De Vrieze, S., Decostere, B., Dejans, P., Dumoulin, A., De Clerck, K., Westbroek, P., Van Hulle, S.W.H., 2010. The use of electrospun flat sheet nanofibre membranes in MBR applications. Desalination 257 (1-3), 170-176. http:// dx.doi.org/10.1016/j.desal.2010.02.027.

Daels, N., Radoicic, M., Radetic, M., Van Hulle, S.W.H., De Clerck, K., 2014. Functionalisation of electrospun polymer nanofibre membranes with $\mathrm{TiO}_{2}$ nanoparticles in view of dissolved organic matter photodegradation. Sep. Purif. Technol. 133 (1), 282-290. http://dx.doi.org/10.1016/ j.seppur.2014.06.040.

Decostere, B., Daels, N., De Vrieze, S., Dejans, P., Van Camp, T., Audenaert, W., Hogie, J., Westbroek, P., De Clerck, K., Van Hulle, S., 2009. Performance assessment of electrospun nanofibers for filter applications. Desalination 249 (3), 942-948. http://dx.doi.org/10.1016/j.desal.2009.06.064.

De Schoenmaker, B., 2013. Electrospinning and Characterisation of Polyamide Nanofibres for Composite Applications. Ghent University, Department of Textiles, Ghent, Belgium, ISBN 9789085786191, p. 89.

De Witte, B., Dewulf, J., Demeestere, K., Van Langenhove, H., 2009. Ozonation and advanced oxidation by the peroxone process of ciprofloxacin in water. J. Hazard. Mater. 161 (2-3), 701-708. http://dx.doi.org/10.1016/j.jhazmat.2008.04.021.

Dojcinovic, B.P., Roglic, G.M., Obradovic, B.M., Kuraica, M.M., Kostic, M.M., Nesic, J., Manojlovic, D.D., 2011. Decolorization of reactive textile dyes using water falling film dielectric barrier discharge. J. Hazard. Mater. 192 (2), 763-771. http://dx.doi.org/ 10.1016/j.jhazmat.2011.05.086.

EC, 2000. Directive 2000/60/EC of the European parliament and of the Council of 23 October 2000 establishing a framework for community action in the field of water policy. CELEX-EUR Off. J. L 327, 1-72. CELEX: 32000L0060.

EC, 2006. Directive 2006/118/EC of the European parliament and of the Council of 12 December 2006 on the protection of groundwater against pollution and deterioration. Off. J. Eur. Union L 372. Annex I, p. 26, CELEX: 32006L0118.

EEA, 2012. European Waters - Assessment of Status and Pressures. European Environment Agency. Report No 8/2012.

Fischbacher, A., von Sonntag, J., von Sonntag, C., Schmidt, T.C., 2013. The $\bullet \mathrm{OH}$ radical yield in the $\mathrm{H}_{2} \mathrm{O}_{2}+\mathrm{O}_{3}$ (peroxone) reaction. Environ. Sci. Technol. 47 (17), 9959-9964. http:// dx.doi.org/10.1021/es402305r.

Glaze, W.H., Kang, J.-W., Chapin, D.H., 1987. The chemistry of water treatment processes involving ozone, hydrogen peroxide and ultraviolet radiation. Ozone: Sci. Eng. J. Int. 
Ozone Assoc. 9 (4), 335-352. http://dx.doi.org/10.1080/ 01919518708552148.

Gong, A., Ye, C., 1998. Analysis of trace atrazine and simazine in environmental samples by liquid chromatography-fluorescence detection with pre-column derivatization reaction. J. Chromatogr. A 827 (1), 57-63. http:// dx.doi.org/10.1016/S0021-9673(98)00742-0.

Gonzalez, M.C., Braun, A.M., Prevot, A.B., Pelizzetti, E., 1994. Vacuum-ultraviolet (VUV) photolysis of water: mineralization of atrazine. Chemosphere 28 (12), 2121-2127. http:// dx.doi.org/10.1016/0045-6535(94)90180-5.

Grabowski, L.R., van Veldhuizen, E.M., Pemen, A.J.M., Rutgers, W.R., 2006. Corona above water reactor for systematic study of aqueous phenol degradation. Plasma Chem. Plasma Process. 26 (1), 3-17. http://dx.doi.org/10.1007/s11090-005-8721-8.

Grymonpre, D.R., Finney, W.C., Clark, R.J., Locke, B.R., 2004. Hybrid gas-liquid electrical discharge reactors for organic compound degradation. Ind. Eng. Chem. Res. 43 (9), 1975-1989. http://dx.doi.org/10.1021/ie030620j.

Hijosa-Valsero, M., Molina, R., Schikora, H., Müller, M., Bayona, J.M., 2013. Removal of priority pollutants from water by means of dielectric barrier discharge atmospheric plasma. J. Hazard. Mater. 262 (1), 664-673. http://dx.doi.org/10.1016/ j.jhazmat.2013.09.022.

Hoeben, W.F.L.M., 2000. Pulsed Corona-induced Degradation of Organic Materials in Water. Technische Universiteit Eindhoven, Eindhoven, the Netherlands, ISBN 90-386-1549-3.

Hong, A., Zappi, M., Kuo, C., Hill, D., 1996. Modeling kinetics of illuminated and dark advanced oxidation processes. J. Environ. Eng. 122 (1), 58-62. http://dx.doi.org/10.1061/(ASCE) 0733-9372(1996)122:1(58).

Hsu, Y.C., Chen, Y.F., Chen, J.H., 2003. Peroxone process for RO-16 and RB-19 dye solutions treatment. J. Environ. Sci. Health Part A Toxic/Hazardous Subst. Environ. Eng. 38 (7), 1361-1376. http://dx.doi.org/10.1081/ESE-120021131.

Jiang, B., Zheng, J., Qiu, S., Wu, M., Zhang, Q., Yan, Z., Xue, Q., 2014. Review on electrical discharge plasma technology for wastewater remediation. Chem. Eng. J. 236 (1), 348-368. http:// dx.doi.org/10.1016/j.cej.2013.09.090.

Kalra, S.S., Mohan, S., Sinha, A., Singh, G., 2011. Advanced oxidation processes for treatment of textile and dye wastewater: a review. In: 2nd International Conference on Environmental Science and Development IPCBEE, vol. 4. IACSIT Press, Singapore, pp. 271-275, 1.

Khan, J.A., He, X., Shah, N.S., Khan, H.M., Hapeshi, E., FattaKassinos, D., Dionysiou, D.D., 2014. Kinetic and mechanism investigation on the photochemical degradation of atrazine with activated $\mathrm{H}_{2} \mathrm{O}_{2}, \mathrm{~S}_{2} \mathrm{O}_{8}^{2-}$ and $\mathrm{HSO}_{5}^{-}$. Chem. Eng. J. 252 (1), 393-403. http://dx.doi.org/10.1016/j.cej.2014.04.104.

Kuosa, M., 2008. Modeling Reaction Kinetics and Mass Transfer in Ozonation in Water Solutions. Acta Universitatis Lappeenrantaensis 331, Lappeenranta University of Technology, Lappeenranta, Finland, ISBN 978-952-214-670-0, p. 82.

Locke, B.R., Thagard, S.M., 2009. Analysis of chemical reactions in gliding-arc reactors with water spray into flowing oxygen. IEEE Trans. Plasma Sci. 37 (4), 494-501. http://dx.doi.org/10.1109/ TPS.2008.2011797.

Locke, B.R., Shih, K.-Y., 2011. Review of the methods to form hydrogen peroxide in electrical discharge plasma with liquid water. Plasma Sources Sci. Technol. 20 (3), 034006-034021. http://dx.doi.org/10.1088/0963-0252/20/3/034006.

Lukes, P., Clupek, M., Babicky, V., Janda, V., Sunka, P., 2005. Generation of ozone by pulsed corona discharge over water surface in hybrid gas-liquid electrical discharge reactor. J. Phys. D: Appl. Phys. 38 (3), 409-416. http://dx.doi.org/10.1088/ 0022-3727/38/3/010.

Lukes, P., Clupek, M., Babicky, V., Spetlikova, E., Sisrova, I., Marsalkova, E., Marsalek, B., 2013. High power DC diaphragm discharge excited in a vapor bubble for the treatment of Water. Plasma Chem. Plasma Process. 33 (1), 83-95. http:// dx.doi.org/10.1007/s11090-012-9432-6.

Magureanu, M., Piroi, D., Mandache, N.B., Parvulescu, V., 2008. Decomposition of methylene blue in water using a dielectric barrier discharge: optimization of the operating parameters. J. Appl. Phys. 104 (10), 103306. http://dx.doi.org/10.1063/1.3021452.

Mededovic, S., Locke, B.R., 2007. Side-chain degradation of atrazine by pulsed electrical discharge in water. Ind. Eng. Chem. Res. 46 (9), 2702-2709. http://dx.doi.org/10.1021/ ie070020a.

Munter, R., 2001. Advanced oxidation processes - current status and prospects. Proc. Est. Acad. Sci. Chem. 50 (2), 59-80. http:// dx.doi.org/10.1002/chin.200141291.

Nikiforov, A., Leys, C., 2006. Surface treatment of cotton yarn by underwater capillary electrical discharge. Plasma Chem. Plasma Process. 26 (4), 415-423. http://dx.doi.org/10.1007/ s11090-006-9021-7.

Nogueira, R.F.P., Oliveira, M.C., Paterlini, W.C., 2005. Simple and fast spectrophotometric determination of $\mathrm{H}_{2} \mathrm{O}_{2}$ in photoFenton reactions using metavanadate. Talanta 66 (1), 86-91. http://dx.doi.org/10.1016/j.talanta.2004.10.001.

Pashaei, S., Siddaramaiah, Avval, M.M., Syed, A.A., 2011. Thermal degradation kinetics of nylon6/GF/crysnano nanoclay nanocomposites by TGA. Chem. Ind. Chem. Eng. Q. 17 (2), 141-151. http://dx.doi.org/10.2298/CICEQ101007064P.

Pelizzetti, E., Maurino, V., Minero, C., Carlin, V., Tosato, M.L., Pramauro, E., Zerbinati, O., 1990. Photocatalytic degradation of atrazine and other s-triazine herbicides. Environ. Sci. Technol. 24 (10), 1559-1565. http://dx.doi.org/10.1021/es00080a016.

Schwarzenbach, R.P., Escher, B.I., Fenner, K., Hofstetter, T.B., Johnson, C.A., von Gunten, U., Wehrli, B., 2006. The challenge of micropollutants in aquatic systems. Science 313 (5790), 1072-1077. http://dx.doi.org/10.1126/science.1127291.

Sugiarto, A.T., Ito, S., Ohshima, T., Sato, M., Skalny, J.D., 2003. Oxidative decoloration of dyes by pulsed discharge plasma in water. J. Electrost. 58 (1-2), 135-145. http://dx.doi.org/10.1016/ S0304-3886(02)00203-6.

Sunka, P., 2001. Pulse electrical discharges in water and their applications. Phys. Plasmas 8 (5), 2587-2594. http://dx.doi.org/ 10.1063/1.1356742.

Ternes, T., Joss, A., Siegrist, H., 2004. Scrutinizing pharmaceuticals and personal care products in wastewater treatment. Environ. Sci. Technol. 38 (20), 392A-399A. http:// dx.doi.org/10.1021/es040639t.

Toth, J., 2002. Adsorption: Theory, Modeling, and Analysis. Surfactant Science Series 107, first ed., ISBN 0-8247-0747-8, p. 105 Marcel Dekker AG, Basel, Switzerland.

UKWIR, 2009. Endocrine Disrupting Chemicals National Demonstration Programme: Assessment of the Performance of WwTW in Removing Oestrogenic Substances (09/TX/04/16). UK Water Industry Research, ISBN 1-84057-525-5.

U.S. EPA, 2007. Atrazine. Toxicity and Exposure Assessment for Children's Health (TEACH) Chemical Summaries (last revised 24.04.07.), p. 6.

Van De Velde, F., De Baets, P., 1997. The friction and wear behaviour of polyamide 6 sliding against steel at low velocity under very high contact pressures. Wear 209 (1-2), 106-114. http://dx.doi.org/10.1016/S0043-1648(96)07500-X.

WHO, 2008 World Health Organisation Guidelines for Drinkingwater Quality: Incorporating 1st and 2nd Addenda, Recommendations third ed., vol. 1, ISBN 978-92-4-154761-1, p. 191 Geneva, Switzerland.

Xu, L.J., Chu, W., Graham, N., 2014. Atrazine degradation using chemical-free process of USUV: analysis of the microheterogeneous environments and the degradation mechanisms. J. Hazard. Mater. 275 (1), 166-174. http:// dx.doi.org/10.1016/j.jhazmat.2014.05.007. 